\title{
Sınıf Öğretmeni ve Sınıf Öğretmeni Adayları Dijital Öykü Atölyesinde ${ }^{1}$
}

\author{
Güler Göçen Kabaran² \\ Bilge Aslan Altan ${ }^{4}$
}

\author{
Halit Karalar ${ }^{3}$ \\ Sedat Altıntaş 5
}

Type/Tür:

Research/Araştırma

Received/Geliş Tarihi:

October 11/ 11 Ekim 2018

Accepted/Kabul Tarihi:

February 19/ 19 Şubat 2019

Page numbers/Sayfa No:

235-257

Corresponding

Author/Illetişimden

Sorumlu Yazar:

gulergocen@mu.edu.tr

\section{$\checkmark$ iThenticate}

This paper was checked for plagiarism using iThenticate during the preview process and before publication. / $\mathrm{Bu}$ çalışma ön inceleme sürecinde ve yayımlanmadan önce iThenticate yazılımı ile taranmıştır.

Copyright $(2019$ by Cumhuriyet University, Faculty of Education. All rights reserved.

\section{Öz}

$\mathrm{Bu}$ araştırmanın amacı TÜBİTAK tarafından desteklenen proje kapsamında gerçekleştirilen dijital öykü atölyesi etkinliklerinin katılımcıların bilgisayar destekli eğitim yapmaya ilişkin tutumları üzerindeki etkisini belirlemek ve proje sürecindeki deneyimlerini incelemektir. Araştırmada karma yöntem araştırmalarından iç içe karma desen tercih kullanılmıştır. Araştırma çalışma grubunun belirlenmesinde amaçlı örnekleme türlerinden ölçüt örnekleme yöntemi kullanılmıştır. Projenin birinci aşaması için katılımcı olarak Türkiye'nin yedi farklı bölgesinde görev yapan 28 sinıf öğretmeni, projenin ikinci aşaması için ise katılımcı olarak farklı üniversitelerde öğrenim gören 28 sinıf öğretmeni adayı belirlenmiştir. Araştırma verilerinin elde edilmesi amacıyla "Bilgisayar Destekli Eğitim Yapmaya İlişkin Tutum Ölçeği" ile araştırmacılar tarafından geliştirilen görüşme formu kullanılmıştır. Nicel verilerin analizinde Shapiro-Wilks ve Levene'nin Varyansların Homojenliği testi, Wilcoxon İşaretli Sıralar testi kullanılmıştır. Nitel verilerin analizinde içerik analizinden faydalanılmışır. Elde edilen bulgulara göre uygulamalar sonrasında katılımcıların bilgisayar destekli eğitim yapmaya ilişkin tutum puanlarının artmış olduğu ancak istatistiksel olarak bu artışın anlamlı olmadığı belirlenmiştir. Katılımcıların dijital öykülemeyi uygulanabilir buldukları ve dijital öykülemenin birçok katkısı olduğunu düşündükleri tespit edilmiştir. Katılımcılar bu süreç içinde uygulamalara, proje ekibine ve diğer katılımcılara yönelik olumlu duygu ve düşünceye sahip olduklarını belirtmişlerdir. Süreç içerisinde zamanın kısa olmasından dolayı sorun yaşadıklarını ifade etmişlerdir. Katılımcılar bu tarz projelerin devam etmesi gerektiğini belirtmişlerdir. Genel olarak katılımcıların proje deneyimlerinin olumlu olduğu belirlenmiştir.

Anahtar Kelimeler: Dijital öykü, sınıf öğretmeni, öğretmen adayı, TÜBİTAK, proje

\section{Suggested APA Citation/Önerilen APA Atıf Biçimi:}

Göçen Kabaran, G., Karalar, H., Aslan Altan, B. ve Altıntaş, S. (2019). Sınıf öğretmeni ve sınıf öğretmeni adayları dijital öykü atölyesinde. Cumhuriyet International Journal of Education, 8(1), 235-257. http://dx.doi.org/10.30703/cije.469461

\footnotetext{
${ }^{1}$ Bu çalışma Tübitak 4004 kapsamında desteklenen 116B192 nolu projeden üretilmiştir.

2 Arş. Gör., Muğla Sıtkı Koçman Üniversitesi, Eğitim Programları ve Öğretim Bölümü, Muğla/Türkiye

Res. Assist., Muğla Sıtkı Koçman University, Department of Curriculum and Instruction, Muğla/Turkey e-mail: gulergocen@mu.edu.tr ORCID ID: https:/ / orcid.org/0000-0002-2631-8768

${ }^{3}$ Dr. Öğr. Üyesi., Muğla Sıtkı Koçman Üniversitesi, Bilgisayar ve Öğretim Teknolojileri Eğitimi Bölümü, Muğla/Türkiye

Asst. Prof. Dr., Muğla Sıtkı Koçman University, Department of Computer Education and Instructional Technology, Muğla/Turkey

e-mail: khalit@ mu.edu.tr ORCID ID: https:// orcid.org/0000-0001-9344-9672

${ }^{4}$ Arş. Gör., Muğla Sıtkı Koçman Üniversitesi, Eğitim Programları ve Öğretim Bölümü, Muğla/Türkiye

Res. Assist., Muğla Sıtkı Koçman University, Department of Curriculum and Instruction, Muğla/Turkey

e-mail: bilgeaslan@mu.edu.tr ORCID ID: https://orcid.org/0000-0002-3309-933X

${ }^{5}$ Arş. Gör., Muğla Sıtkı Koçman Üniversitesi, Eğitim Programları ve Öğretim Bölümü, Muğla/Türkiye

Res. Assist., Muğla Sıtkı Koçman University, Department of Curriculum and Instruction, Muğla/Turkey

e-mail: sedataltintas@ mu.edu.tr ORCID ID: https:/ / orcid.org/0000-0002-6269-5376
} 


\title{
In-service and Preservice Classroom Teachers in Digital Story Workshop
}

\begin{abstract}
The purpose of this study is to determine the effect of digital story workshop activities within the scope of the project supported by TUBITAK on the attitudes of the participants towards computer aided education and to examine their experiences in the project process. In this study, mixed method research has been used. Criterion sampling method was used for determining the research study group. For the first section of the project, 28 primary education teachers working in seven different regions of Turkey were selected. In the second section, 28 prospective primary education teaches studying in different universities were selected. In order to obtain the research data "The Attitude Scale Toward Making Computer Supported Education" and the interview form developed by the researchers were used. In the analysis of quantitative data, Shapiro-Wilks, Levene's Homogeneity of Variances and Wilcoxon Signed Rank test were used. Content analysis was used in the analysis of qualitative data. According to the findings, it was determined that the attitude scores of the participants regarding computer aided education increased after the applications, but this increase was not statistically significant. Participants stated that digital storytelling was found to be feasible and that digital storytelling contributed to the study. Participants stated that they had positive feelings and thoughts about the applications, project team and other participants. They stated that they experienced problems due to the short time in the process. Participants stated that such projects should continue. Overall, the project experience of the participants was found to be positive.
\end{abstract}

Keywords: Digital story, classroom teacher, teacher candidate, TÜBİTAK, project

\section{Giriş}

Gelişen ve değişen dünya eğitim ortamlarında kullanılan yöntem, teknik ve materyalleri de değişmesine neden olmuştur. Özellikle bilgi ve iletişim teknolojilerinde yaşanan gelişmeler, hızla devam eden teknoloji entegrasyonu çalışmaları artık eğitim-öğretim ortamlarında teknolojik uygulamaların varlığını beraberinde getirmiştir. Yılmaz, Üstündağ ve Güneş (2017), eğitimde BİT'in kullanımında pedagojiden çok teknolojik gelişmeler ve yeterlilikler üzerinde durulduğundan bahsederek bu entegrasyonun sağlıklı bir şekilde gerçekleştirilebilmesi için teknolojinin diğer faktörlerle birlikte ele alınmasının daha doğru olacağına vurgu yapmışlardır. Bu doğrultuda öğretme-öğrenme süreçlerinde kullanılan teknolojik uygulamaların pedagojik özelliklerinin de dikkate alınması gerekliliği ortaya çıkmaktadır. Dijital öyküleme yöntemi, geleneksel öyküleme yöntemine teknoloji boyutunun eklenmesi ile ortaya çıkmış bir yöntem olarak bu durum için bir örnek teşkil etmektedir.

Dijital öykülemenin temeli geçmişten günümüze kadar kullanılan bir eğitim aracı olan öykülemeden gelmektedir. Mello (2001) tarafından belirtildiği gibi öyküleme düşünce ve imgelerin anlatılmasında kullanılan en eski metotlardan birisidir. Dijital öyküleme ise bilgisayar, video kamera ve ses kaydedici gibi kişisel dijital teknolojiler ile geleneksel bir öykünün birleştirildiği yaratıcı bir süreç olarak tanımlanmaktadır (Ohler, 2008). Bu bağlamda dijital öykülemenin geleneksel öyküleme yönteminin dijital bir formu olduğu söylenebilir. Dijital öyküleme çalışmaları 1994 yılında San Francisco'da kurulan Dijital Medya Merkezi'nde başlatılmıştır. Günümüzde ise yurtdışında okulöncesi eğitimden yetişkin eğitimine 
kadar yaygın bir biçimde kullanılmaya başlanmıştır. Ülkemizde de son zamanlarda dijital öyküleme ile ilgili çalışmalar hız kazanmıştır.

Robin (2006), dijital öykülemeyi "kişisel öyküler", "tarihsel olayları inceleyen öyküler" ve "bilgilendirme veya öğretim öyküleri" şeklinde gruplandırmıştır. Eğitim alanında kullanılan dijital öyküler genel olarak bilgilendirme veya öğretim öyküleri kategorisinde yer almaktadır. Bu tür dijital öykülerde bilgi verilecek ya da öğretimi yapılacak konu öyküleştirilerek uygun görüntü, ses ve müzikle birleştirilip hedef kitleye sunulmaktadır. Bu bağlamda dijital öykülemenin teknik bilgi, alan bilgisi ve pedagoji bilgisi boyutlarını bir arada barındırdığı söylenebilir. Teknik bilgi boyutu dijital öykünün hazırlanmasında kullanılan araç-gereç ve programları ifade etmektedir. İnceelli (2005), dijital öykülemenin teknolojik gelişmeler ile daha farklı cihazlar ve yöntemlerle yapılmaya başlandığından bahsetmektedir. Bununla birlikte dijital öykülemenin multimedya unsurlarının kullanımını gerektirdiği belirtilmektedir (Michalski, Hodges ve Banister, 2005). İlgili literatürde dijital öykü hazırlanmasında Microsoft Photo Story 3, Windows Movie Maker, Apple iMovie, Audacity, Photoshop Elements, Animoto, Meograph, Prezi, VoiceThread, WeVideo, Com-Phone Story Maker, iMovie, StoryKit, Storyrobe gibi program, uygulama veya yazılımların kullanılabileceği belirtilmektedir (Chung, 2007; Educational Uses of Digital Storytelling, 2017; Robin ve McNeil, 2012). Alan bilgisi, öğretim ve aktarım sürecinde belirlenen ve hedeflenen konu alanını kapsayan bilgi birikimi olarak ifade edilmektedir (Koehler ve Mishra, 2008). Dijital öyküleme sürecinde alan bilgisi boyutu içerik olan seçilen konu hakkında gerekli kavram, bilgi ve teorileri içermekte ve süreçte bu bilgilerin kullanımını gerektirmektedir. Pedagojik bilgi öğretme ve öğrenme ile ilgili her türlü planlama, yöntem, metot ve diğer bilgileri kapsamaktadır (Pamuk, Ülken ve Dilek, 2012). Bu doğrultuda pedagoji bilgisi boyutunun hazırlanacak dijital öykünün hedef kitlenin özelliklerine uygun yöntem, strateji ve tekniklerle planlanmasını içerdiği söylenebilir. Dijital öyküleme yöntemi içermiş olduğu bu üç boyut göz önüne alındığında günümüz gerekliliklerinden görünen teknopedagojik eğitime uygun bir yöntem olarak nitelendirilebilmektedir.

Dijital öyküleme yöntemi günümüz öğrencilerinin beklentilerini karşılayacak ve onları öğretme-öğrenme süreçlerinde aktif kılacak bir yöntem olarak görülmektedir. Yapılan araştırmalar dijital öyküleme yönteminin öğrenciler üzerinde olumlu etkilerini ortaya koymaktadır. Dijital öyküleme yöntemi öğrencilerin akademik başarılarını artırmakta, derse yönelik olumlu tutum geliştirmelerine katkıda bulunmakta, yazma becerilerini geliştirmekte, eleştirel düşünme ve problem çözme becerilerini geliştirmekte, demokratik değer yargılarını artırmakta, derslerin kalıcılığına ve öğrencilerin kendilerini ifade etmelerine olumlu yönde katkı sağlamaktadır (Balaman, 2016; Foley, 2013; Robin, 2006; Tatlı ve Aksoy, 2017; Yang ve $\mathrm{Wu}, 2012 ;$ Yoon, 2013). Öğrenciler açısından bu katkıları göz önüne alındığında dijital öyküleme yönteminin öğretmenler tarafından kullanılmasının öğretim sürecine olumlu yönde katk1 sağlayacağı düşünülmektedir. $\mathrm{Bu}$ bağlamda araştırmada aktif olarak öğretmenlik mesleğini yürüten kişilere ve mesleğe henüz başlamamış olan öğretmen adaylarına bu yöntemin teorik ve uygulama boyutlarının etkileşimli bir biçimde verildiği bir proje çalışması gerçekleştirilmiştir. 
Araştırmanın amacı proje kapsamında gerçekleştirilen dijital öykü atölyesi etkinliklerinin katılımcıların bilgisayar destekli eğitim yapmaya ilişkin tutumları üzerindeki etkisini belirlemek ve proje sürecindeki deneyimlerini incelemektir. Bu doğrultuda araştırmada şu sorulara cevap aranmıştır:

1. Sınıf öğretmenlerinin dijital öykü atölyesi etkinlikleri sonrasında bilgisayar destekli eğitim yapmaya ilişkin tutumları anlamlı bir biçimde farklılaşmakta midır?

2. Sınıf öğretmeni adaylarının dijital öykü atölyesi etkinlikleri sonrasında bilgisayar destekli eğitim yapmaya ilişkin tutumları anlamlı bir biçimde farklılaşmakta midır?

3. Sınıf öğretmeni ve sınıf öğretmeni adaylarının dijital öyküleme sürecine ilişkin görüşleri nelerdir?

4. Sınıf öğretmeni ve sınıf öğretmeni adaylarının dijital öykü atölyesi projesine ilişkin görüşleri nelerdir?

5. Sınıf öğretmeni ve sınıf öğretmeni adaylarının dijital öykü atölyesi projesinde yaşadıkları sorunlar ve çözüm önerileri nelerdir?

\section{Araştırmanın Modeli}

\section{Yöntem}

$\mathrm{Bu}$ araştırmada son yıllarda sosyal bilimlerde sıklıkla kullanılan karma yöntem araştırması modeli kullanılmıştır. Karma desende ana fikir nitel ve nicel verilerin birlikte kullanılması ile araştırma probleminin bu desenlerden herhangi birinin kullanıldığı durumlara göre daha iyi anlaşılacak olmasıdır (Creswell, 2012). Araştırmada karma yöntem araştırmalarından iç içe karma desen tercih edilmiştir. İç içe karma desende amaç nitel ve nicel verilerin eş zamanlı veya sıralı olarak toplanmasıdır. Bu farklı veri çeşitleri birbirini destekleyici roldedir. Bu desende nicel verilerin uygulamanın sonuçları üzerinde bir etkisi olup olmadığını ele almak, nitel verilerin ise katılımcıların uygulama esnasındaki deneyimlerini değerlendirmek için kullanılabileceği belirtilmiştir (Creswell ve Plano Clark, 2015). Araştırmada dijital öykü atölyesinde gerçekleştirilen etkinliklerin katılımcıların bilgisayar destekli eğitim yapmaya ilişkin tutumlarına etkisini belirlemek ve proje sürecindeki deneyimlerini değerlendirmek söz konusu olduğu için bu desen tercih edilmiştir.

\section{Çalışma Grubu}

Araştırma çalışma grubunun belirlenmesinde amaçlı örnekleme türlerinden ölçüt örnekleme yöntemi kullanılmıştır. Projenin etkinliklerinin sınıf öğretmenleri ve sınıf öğretmeni adaylarına uygun olarak planlanması nedeniyle amaçlı örnekleme tercih edilmiştir. Aynı zamanda projenin yaygın etkisinin sağlanması proje ekibi tarafından her bölgeden iki kadın iki erkek olmak üzere dört sınıf öğretmeni ve dört sınıf öğretmeni adayı alınması ölçüt olarak belirlenmiştir. Projenin birinci aşaması için katılımcı olarak 28 sınıf öğretmeni, projenin ikinci aşaması için ise katılımcı olarak 28 sınıf öğretmeni adayı belirlenmiştir.

\section{Veri Toplama Araçları}

Araştırma verilerinin elde edilmesi amacıyla Arslan (2006) tarafından geliştirilen "Bilgisayar Destekli Eğitim Yapmaya İlişkin Tutum Ölçeği" ile araştırmacılar tarafından geliştirilen görüşme formu kullanılmıştır. 
Bilgisayar Destekli Eğitim Yapmaya İlişkin Tutum Ölçeği, 20 maddeden oluşan 5'li likert tipindedir. Ölçek maddelerinin 10'u olumlu, 10'u olumsuz özellik göstermektedir. Ölçeğin Kaiser-Meyer-Olkin (KMO) katsayısı 0.88, Barlett Testi anlamlılık değeri 0.000 bulunmuştur. Ölçeğin Cronbach-alpha güvenirlik katsayısı 0.93 olarak bulunmuştur (Arslan, 2006). Bu araştırmada hesaplanan güvenirlik katsayısı .89 olarak bulunmuştur.

Çalışma grubunun proje etkinlikleri sonunda görüşlerini almak için araştırmacılar tarafından anket formu geliştirilmiştir. Anket formunda seçmeli ve açık uçlu sorular yer almaktadır. Form ile katılımcıların dijital öyküleme yöntemine ve proje uygulama sürecine ilişkin görüşlerinin alınması amaçlanmıştır Anket formunun hazırlanma sürecinde uzman görüşüne başvurulmuştur. Uzmanlardan gelen görüşler doğrultusunda anket formunda yer alan bazı sorular çıkartılmış bazı sorular ise revize edilerek ankete son hali verilmiştir.

\section{Uygulama Süreci}

Proje uygulamaları iki aşamada gerçekleştirilmiştir. İlk aşama olan "Sınıf Öğretmenleri Dijital Öykü Atölyesinde" Türkiye'nin yedi farklı bölgesinden gelmekte olan 28 sınıf ögrretmeninin katılımı ile gerçekleştirilmiştir. İkinci aşama olan “Sınıf Öğretmeni Adayları Dijital Öykü Atölyesinde" 28 öğretmen adayının katılımı ile gerçekleştirilmiştir. Katılımcılar proje sürecinde konaklamalı olarak etkinliklere katılmışlardır. Öğretmenler ve öğretmen adayları için daha önceden araştırmacılar tarafından hazırlanan etkinlikler dörder gün boyunca uygulanmıştır. Proje sürecinde gerçekleştirilen etkinlikler ve bu etkinliklerin amaçları Ek'te (s. 255) gösterilmiştir.

Etkinlikler katılımcılarla grup çalışması şeklinde gerçekleştirilmiştir. İki aşamada da dörder kişilik yedi grup oluşturulmuştur. Bu sayede katılımcıların etkinliklerini beyin fırtınası yaparak gerçekleştirmelerine olanak sağlanmıştır. Proje sonucunda hem öğretmen hem de öğretmen adayları grup olarak kendi dijital öykülerini oluşturmuşlardır.

\section{Verilerin Analizi}

Araştırmada nicel verilerin analizinde SPSS paket programı kullanılmıştır. Analizler iki aşama için ayrı ayrı gerçekleştirilmiştir. Öncelikle katılımcıların öntest sontest puanlarının normallik ve homojenlik dağılımları için Shapiro-Wilks ve Levene'nin Varyansların Homojenliği testi sonuçları incelenmiştir. Büyüköztürk (2012), grup büyüklüğünün 50'den az olması durumunda puanların normalliğe uygunluğunun Shapiro-Wilks testi ile yapılacağını ifade etmiştir. İki aşamada da ayrı ayrı 28 katılımcı olduğu için normallik dağılımında bu testin incelenmesi uygun görülmüştür. Ayrıca normallik için çarpıklık ve basıklık değerleri de incelenmiştir. Öntest sontest puanlarının karşılaştırılmasında Wilcoxon İşaretli Sıralar testi yapılmıştır. Nitel verilerin analizinde içerik analizi kullanılmıştır. İçerik analizinde temelde yapılan işlem, birbirine benzeyen verileri belirli kavramlar ve temalar çerçevesinde bir araya getirmek ve bunları okuyucunun anlayabileceği bir biçimde yorumlamaktır (Yıldırım ve Şimşek, 2016). Bu kapsamda görüşme sorularından elde edilen veriler temalar, alt temalar ve kodlar şeklinde organize edilerek detaylı bir biçimde sunulmuştur. 


\section{Birinci Alt Probleme İlişkin Bulgular}

\section{Bulgular}

"Sınıf öğretmenlerinin dijital öykü atölyesi etkinlikleri sonrasında bilgisayar destekli eğitim yapmaya ilişkin tutumları anlamlı bir biçimde farklılaşmakta mıdır?" sorusunu cevaplandırmak üzere öğretmenlerin ölçekten aldıkları puanların normallik ve homojenlik dağılımları incelenmiş ve sonuçlar Tablo 1'de gösterilmiştir.

Tablo 1

Öğretmenlerin Öntest Sontest Puanlan İçin Normallik ve Homojenlik Analizleri

\begin{tabular}{ccccc}
\hline Puanlar & Çarpıklık & Basıklık & $\begin{array}{c}\text { Shapiro-Wilks } \\
\text { Testi }(\mathrm{p})\end{array}$ & $\begin{array}{c}\text { Levene Testi } \\
(\mathrm{p})\end{array}$ \\
\hline Katsayıs1 & Katsayıs1 & -.1 .030 & .057 & .857 \\
Sontest & -.355 & -.109 & .001 & .857 \\
\hline
\end{tabular}

Tablo 1 incelendiğinde öğretmenlerin öntest puanlarının normal dağıldı ̆̆ ancak sontest puanlarının normal dağılmadığı görülmektedir. Bu nedenle analizlerde non-parametrik testlerden Wilcoxon İşaretli Sıralar Testi kullanılmış sonuçları Tablo 2 'de verilmiştir.

Tablo 2

Öğretmenlerin Öntest Sontest Puanları Wilcoxon İşaretli Sıralar Testi Sonuçları

\begin{tabular}{cccccc}
\hline Sontest-Öntest & $N$ & Sira Ortalaması & Sira Toplamı & $z$ & $p$ \\
\hline Negatif Sıra & 8 & 13.38 & 107.00 & -1.744 & .081 \\
Pozitif Sıra & 18 & 13.56 & 244.00 & & \\
Eşit & 2 & & & \\
\hline
\end{tabular}

Tablo 2 incelendiğinde öğretmenlerin öntest sontest puanları arasında istatistiksel olarak anlamlı bir farklılık olmadığı görülmektedir. Ancak öğretmenlerin sontest puan ortalamalarınin $(\bar{x}=92.64)$, öntest puan ortalamalarından $(\bar{X}=89.82)$ daha yüksek olduğu belirlenmiştir. Bu sonuca göre yapılan uygulamaların öğretmenlerin bilgisayar destekli eğitim yapmaya ilişkin tutumlarını artırdığını ancak bu artışın istatistiksel olarak anlamlı olmadı̆̆ı söylenebilir.

\section{İkinci Alt Probleme İlişkin Bulgular}

"Sınıf öğretmeni adaylarının dijital öykü atölyesi etkinlikleri sonrasında bilgisayar destekli eğitim yapmaya ilişkin tutumları anlamlı bir biçimde farklılaşmakta mıdır?" sorusunu cevaplandırmak üzere öğretmen adaylarının ölçekten aldıkları puanların normallik ve homojenlik dağılımları incelenmiş ve sonuçlar Tablo 3'te gösterilmiştir.

Tablo 3

Öğrencilerin Öntest Sontest Puanlarn İçin Normallik ve Homojenlik Analizleri

\begin{tabular}{ccccc}
\hline Puanlar & $\begin{array}{c}\text { Çarpıklık } \\
\text { Katsayısı }\end{array}$ & $\begin{array}{c}\text { Basıklık } \\
\text { Katsayısı }\end{array}$ & $\begin{array}{c}\text { Shapiro-Wilks } \\
\text { Testi }(\mathrm{p})\end{array}$ & $\begin{array}{c}\text { Levene } \\
\text { Testi }(\mathrm{p})\end{array}$ \\
\hline Öntest & -.569 & .190 & .498 & .304 \\
Sontest & -1.334 & 3.145 & .004 & \\
\hline
\end{tabular}


Tablo 3 incelendiğinde öğrencilerin öntest puanlarının normal dağıldığ1 ancak sontest puanlarının normal dağılmadığı görülmektedir. Bu nedenle analizlerde non-parametrik testlerden Wilcoxon İşaretli Sıralar Testi kullanılmış sonuçları Tablo 4 'te verilmiştir.

Tablo 4

Öğrencilerin Öntest Sontest Puanları Wilcoxon İşaretli Stralar Testi Sonuçları

\begin{tabular}{cccccc}
\hline Sontest-Öntest & $N$ & $\begin{array}{c}\text { Sıra } \\
\text { Ortalaması }\end{array}$ & Sıra Toplamı & $z$ & $p$ \\
\hline Negatif Sıra & 11 & 13.00 & 143.00 & -.826 & .409 \\
Pozitif Sıra & 15 & 13.87 & 208.00 & & \\
Eşit & 2 & & & & \\
\hline
\end{tabular}

Tablo 4 incelendiğinde öğrencilerin öntest sontest puanları arasında istatistiksel olarak anlamlı bir farklılık olmadığ görülmektedir. Ancak öğrencilerin sontest puan ortalamalarının ( $\bar{x}=88.04)$, öntest puan ortalamalarından $(\bar{x}=86.57)$ daha yüksek olduğu belirlenmiştir. Bu sonuca göre yapılan uygulamaların öğrencilerin bilgisayar destekli eğitim yapmaya ilişkin tutumlarını artırdı̆̆ını ancak bu artışın istatistiksel olarak anlamlı olmadığı söylenebilir.

\section{Üçüncü Alt Probleme İlişkin Bulgular}

"Sınıf öğretmeni ve sınıf öğretmeni adaylarının dijital öyküleme sürecine ilişkin görüşleri nelerdir?" sorusunu cevaplandırmak üzere katılımcıların yöntemin uygulanabilirliği ve katkılarına ilişkin görüşleri incelenmiştir.

Tablo 5

Dijital Öyküleme Yöntemini Uygulanabilir Bulma Durumu

\begin{tabular}{ccccccc}
\hline \multirow{2}{*}{ Katılımcılar } & \multicolumn{2}{c}{ Evet } & \multicolumn{2}{c}{ Hayır } & \multicolumn{2}{c}{ Kısmen } \\
& $f$ & $\%$ & $f$ & $\%$ & $f$ & $\%$ \\
\hline Öğretmen & 27 & 96.4 & 1 & 3.6 & 0 & 0 \\
Öğretmen Adayı & 28 & 100.0 & 0 & 0 & 0 & 0 \\
\hline
\end{tabular}

Tablo 5 incelendiğinde bir katılımcı dışında diğer katılımcıların dijital öyküleme yöntemini uygulanabilir buldukları görülmektedir. Proje uygulamaları sürecinde proje ekibi tarafından verilen eğitimler ve dokümanlar ile katılımcıların bu yöntemi uygulama yeterlikleri oluşturulmaya çalışılmıştır. Elde edilen sonuca göre öğretmenlerin yöntemi uygulama konusunda yeterlik kazandıkları ve uygulanabilir bulduklarını göstermektedir.

Tablo 6 incelendiğinde öğretmen ve öğretmen adaylarının dijital öyküleme sürecince katkısını gördükleri konular yer almaktadır. Öğretmenler dijital öyküleme sürecinin en çok hikâyeleri planlama konusunda yarar sağladığını belirtirken, öğretmen adayları en çok imaj-resim oluşturma ile hikâye ile ilgili materyalleri bütünleştirme konusunda yarar sağladığını belirtmişlerdir. Öğretmen ve öğretmen adayları dijital öyküleme sürecinin bu seçenekler dışında derse dikkat çekmede, kazanımların amacına somut ulaşmasında, teknoloji ile ürün ortaya koymada, 
metnin ana fikrini belirlemede, eleştirel düşünmede ve yaratıcı fikir bulmada katkı sağladığını belirtmişlerdir.

Tablo 6

Dijital Öyküleme Sürecinin Katkıları

\begin{tabular}{lcccc}
\hline \multirow{2}{*}{ Seçenekler } & \multicolumn{2}{c}{ Öğretmen } & \multicolumn{2}{c}{ Öğretmen } \\
& $f$ & $\%$ & $f$ & $\%$ \\
\hline Fikir-konu bulabilme & 19 & 67.9 & 23 & 82.1 \\
Keşfetme ve araştırma neticesinde öğrenme & 17 & 60.7 & 18 & 64.3 \\
Hikâyeleri planlama & 26 & 92.9 & 25 & 89.3 \\
İmaj-resim oluşturma & 20 & 71.4 & 27 & 96.4 \\
Hikâye ile ilgili materyalleri bütünleştirme & 22 & 78.6 & 27 & 96.4 \\
Çalışmalara yönelik düzenli yararlı geribildirimler alma & 16 & 57.1 & 21 & 75.0 \\
Başkalarının çalışmalarına yönelik görüşlerin iletilmesi & 18 & 64.3 & 22 & 78.6 \\
Genel olarak hikâye oluşturma & 24 & 85.7 & 25 & 89.3 \\
Diğer (Lütfen belirtiniz) & 2 & 7.1 & 2 & 7.1 \\
\hline
\end{tabular}

\section{Dördüncü Alt Probleme İlişkin Bulgular}

"Sınıf öğretmeni ve sınıf öğretmeni adaylarının dijital öykü atölyesi projesine ilişkin görüşleri nelerdir?" sorusunu cevaplandırmak üzere katılımcllara bu projede hangi duygu ve düşünceleri yaşadıkları sorulmuştur. Öğretmenlerin ve öğrencilerin bu soruya verdikleri cevaplara göre duygu ve düşünceler ana teması için uygulamalara yönelik, proje ekibine yönelik ve katılımcılara yönelik olmak üzere üç farklı tema geliştirilmiş ve Şekil 1'de gösterilmiştir.

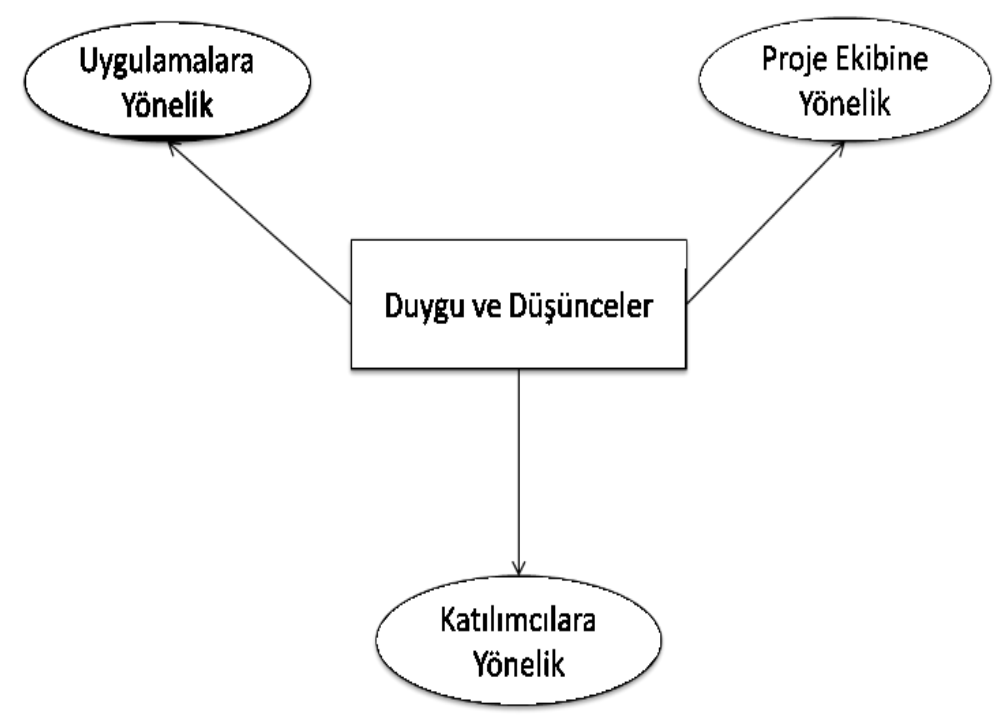

Şekil 1. Duygu ve düşünce temasına ait alt temalar

Öğretmenlerin uygulamalara yönelik duygu ve düşünceleri için elde edilen temalar Şekil 2' de gösterilmiştir. 


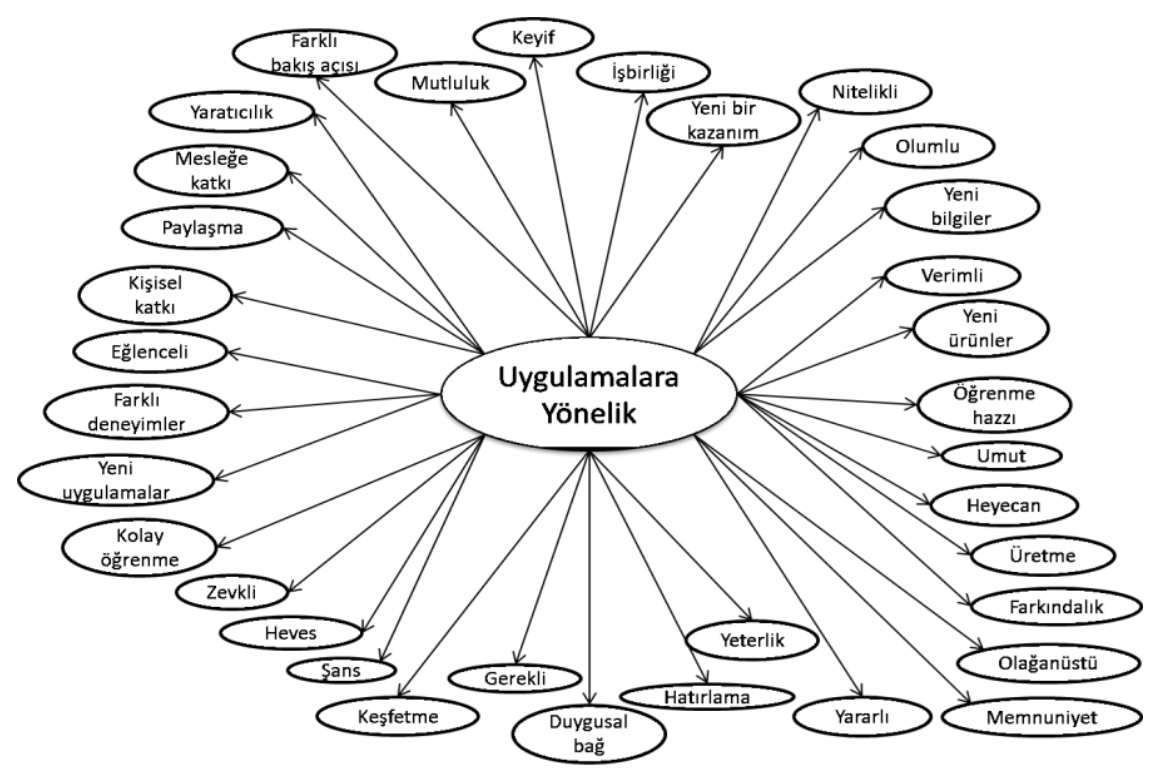

Şekil 2. Öğretmenlerin uygulamalara yönelik duygu ve düşünceleri

Öğretmenler uygulamalara yönelik genel olarak olumlu duygu ve düşüncelere sahip olduklarını belirtmişlerdir. Öğretmenlerin görüşme sorusuna verdikleri cevaplardan örnekler aşağıda verilmiştir.

“Öncelikle bu projeye katılmaktan dolayı çok mutlu olduğumu ifade edeyim. Çok keyifli, verimli zaman geçirdim. Yapılan çalışmalar öğretilen programlar verilen değerli bilgiler bana hem öğretmenlik adına hem de kişisel anlamda çok şey kattı..." (Ö6)

"Teknolojiyi bu denli birebir kullanmam özgün bir hikâye oluşturmak ve bunu ders kazanımlarıyla ilişkilendirmek olağanüstü idi. Heyecan verici, gerçek hayata dair ve kazanımları göz önünde bulundurarak hazırlamak yaratıcılık adına bana çok katkı sağladı." (Ö14)

Öğretmen adaylarının uygulamalara yönelik duygu ve düşünceleri için elde edilen temalar Şekil 3 'te gösterilmiştir.

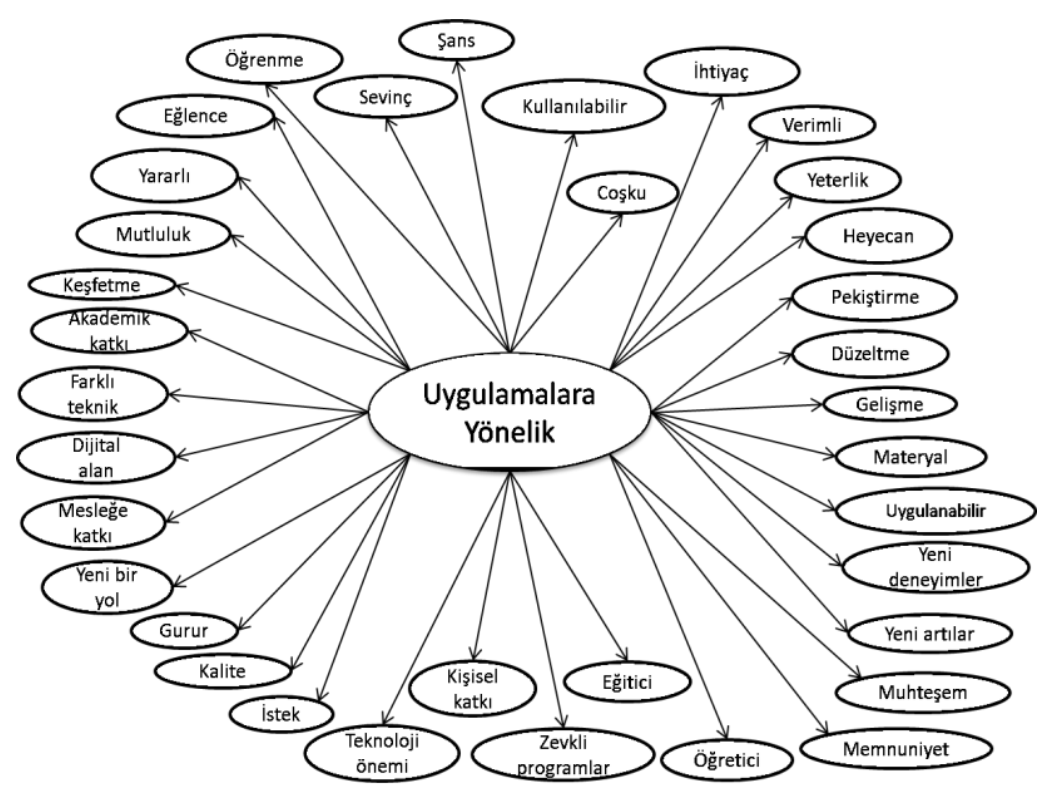

Şekil 3. Öğretmen adaylarının uygulamalara yönelik duygu ve düşünceleri 
Öğrenciler de uygulamalara yönelik genel olarak olumlu duygu ve düşüncelere sahip olduklarını belirtmişlerdir. Öğrencilerin görüşme sorusuna verdikleri cevaplardan örnekler aşağıda verilmiştir.

"Öykülemeye farklı bir teknikle yaklaşmak beni heyecanlandırdı ve duygu olarak coşkuluydum. Öncesinde tanımadı̆̆ım, bilmediğim bir teknik tanıdım, öğrendim. Bundan sonraki mesleki hayatımda sıkça başvuracağım faydalı bir yöntem olduğunu düşünüyorum." (ÖA10)

"Proje ilk günden beri eğlenceli ve verimli geçti. Öykü yazıp çalı̧̧malar yaptık, daha sonra dijital ortamda onlar sunmak çok güzeldi. Çok yararlı ve verimli oldu bence. İlerdeki meslek hayatımızda kullanacağımı elimizde güzel materyallerimiz oldu." (ÖA15)

Öğretmenlerin proje ekibine yönelik duygu ve düşünceleri için elde edilen temalar Şekil 4' de gösterilmiştir.

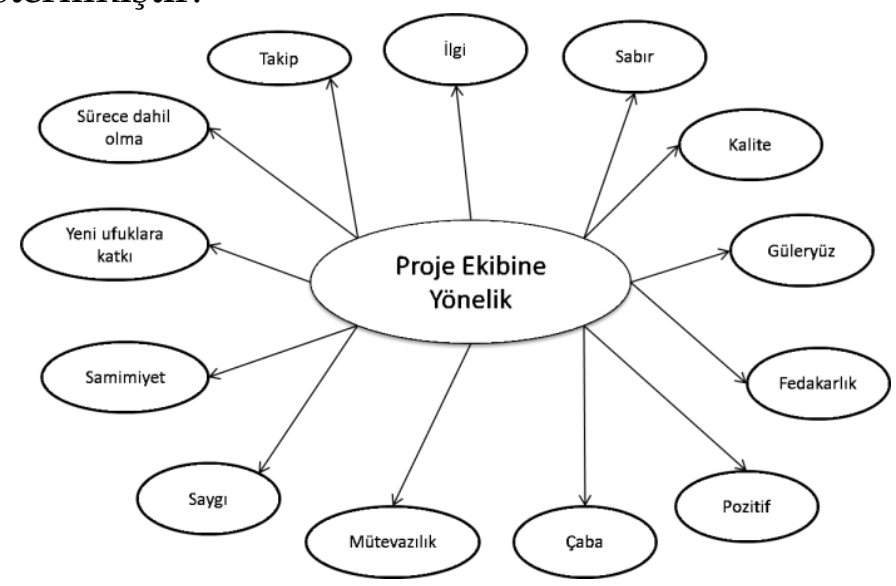

Şekil 4. Öğretmenlerin proje ekibine yönelik duygu ve düşünceleri

Öğretmenler proje ekibine yönelik olumlu duygu ve düşüncelere sahip olduklarını belirtmişlerdir. Öğretmenlerin görüşme sorusuna verdikleri cevaplardan örnekler aşağ 1 da verilmiştir.

"Çok fazla değerli eğiticilerle bir arada bulunduk. Eğitici hocalarımı buradan yeni ufuklar açılmasına katkıda bulundular...." (Ö11).

"...Projede yer alan hazırlayan tüm hocalar güler yüzlü, pozitif ve sabırlydı. Bu da öğrenme sürecimizi zevkli ve keyif düzeyi yüksek hale getirdi" (Ö27)

Öğretmen adaylarının proje ekibine yönelik duygu ve düşünceleri için elde edilen temalar Şekil 5 'te gösterilmiştir.

Öğrenciler de proje ekibine yönelik olumlu duygu ve düşüncelere sahip olduklarını belirtmişlerdir. Öğrencilerin görüşme sorusuna verdikleri cevaplardan örnekler aşağıda verilmiştir.

“... proje ekibinin sıcakkanlılığı sayesinde samimiyetleri sayesinde hiç yabancllk çekmedik. Kendi evimizde gibi hissettiğimiz güzel anılarımız oldu..." (ÖA9)

“.... Kaliteli bir proje ve birbirinden kaliteli eğitmenler tarafindan bizlere verilen eğitim ve deneyim için mutlu ve umutluyum." (ÖA20) 


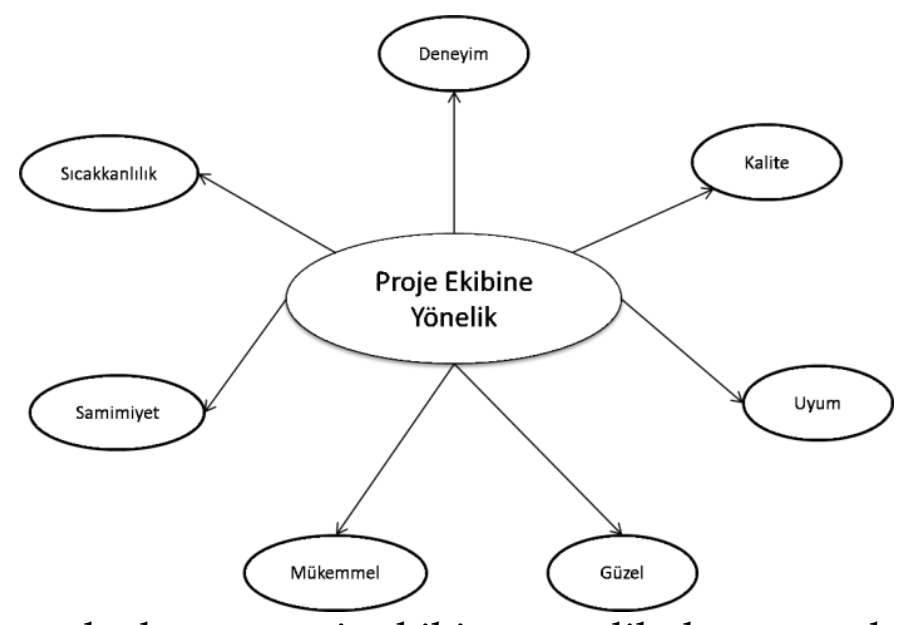

Şekil 5. Öğretmen adaylarının proje ekibine yönelik duygu ve düşünceleri

Öğretmenlerin katılımcılara yönelik duygu ve düşünceleri için elde edilen temalar Şekil 6' da gösterilmiştir.

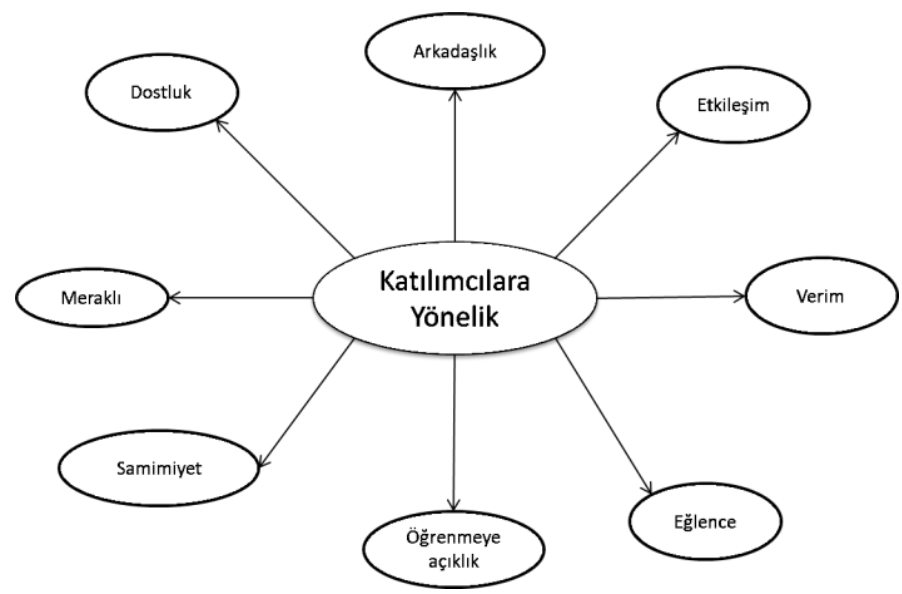

Şekil 6. Öğretmenlerin katılımcılara yönelik duygu ve düşünceleri

Öğretmenler diğer katılımcılara yönelik olumlu duygu ve düşüncelere sahip olduklarını belirtmişlerdir. Öğretmenlerin görüşme sorusuna verdikleri cevaplardan örnekler aşağıda verilmiştir.

"...Proje ekibi ve katılımcılarla aramızda oluşan arkadaşlık, dostluk ve samimi ortam da cabast." (Ö8)

"...Ve grupla olan etkileşim sayesinde pek çok yeni uygulama, eğitimler hakkında bilgi sahibi oldum." (Ö11)

Öğretmen adaylarının katılımcılara yönelik duygu ve düşünceleri için elde edilen temalar Şekil 7' de gösterilmiştir. 


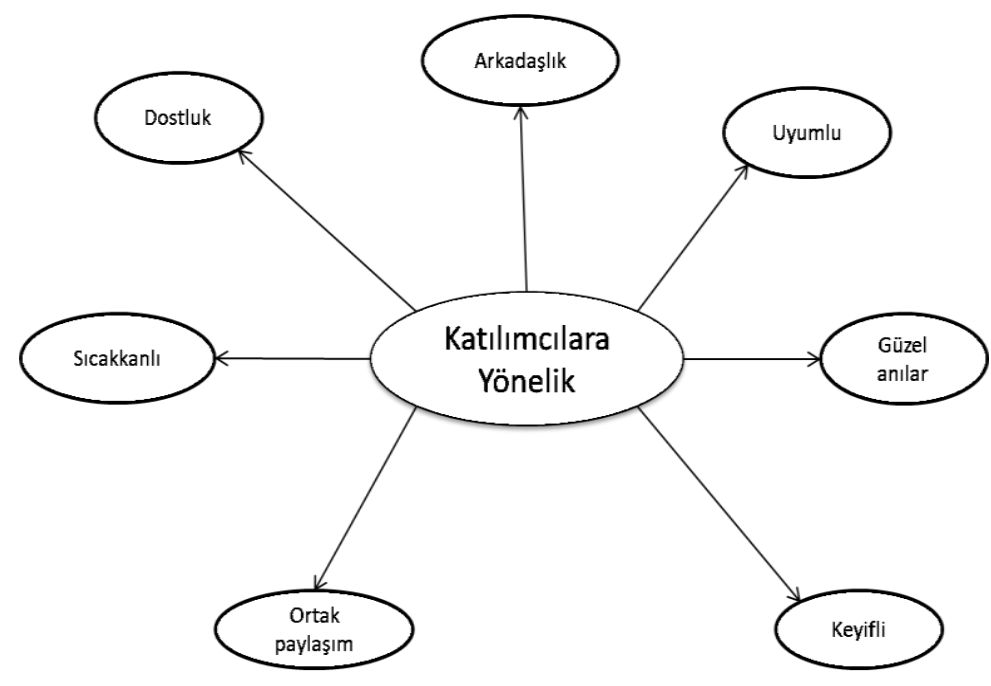

Şekil 7. Öğretmen adaylarının katılımcılara yönelik duygu ve düşünceleri

Öğrenciler diğger katılımcılara yönelik olumlu duygu ve düşüncelere sahip olduklarını belirtmişlerdir. Öğrencilerin görüşme sorusuna verdikleri cevaplardan örnekler aşağıda verilmiştir.

“...Türkiye'nin çok farkl bölgelerinden gelen öğretmen adayları ile tanışma ve fikirlerimizi paylaşma firsatı bulduk..." (ÖA16)

"Farkl üniversitelerden oluşan bir grup ile eğlenceli bir eğitim geçirdim. Keyifli ve verimliydi..." (ÖA28)

\section{Beşinci Alt Probleme İlişkin Bulgular}

"Sınıf öğretmeni ve sınıf öğretmeni adaylarının dijital öykü atölyesi projesinde yaşadıkları sorunlar ve çözüm önerileri nelerdir?" sorusunu cevaplandırmak üzere katılımcılara projede yaşamış oldukları sorunların neler olduğu sorulmuş ve çözüm önerileri geliştirmeleri istenmiştir. Öğretmen ve öğrencilerin soruya verdikleri cevaplara göre sorun ve öneriler ana teması için sorunlar ve öneriler olmak üzere iki farklı tema geliştirilmiş ve Şekil 8'de gösterilmiştir.

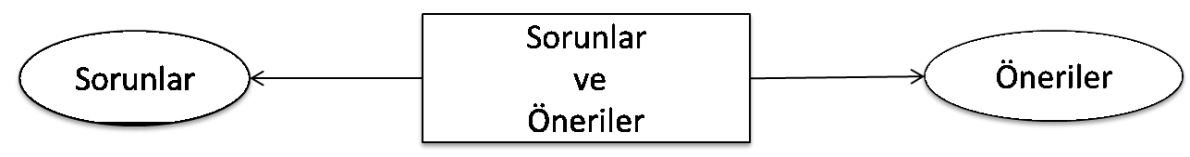

Şekil 8. Sorunlar ve öneriler temasına ait alt temalar

Öğretmenlerin proje sürecinde yaşadıkları sorunlara ilişkin oluşan temalar Şekil 9'da gösterilmiştir. 


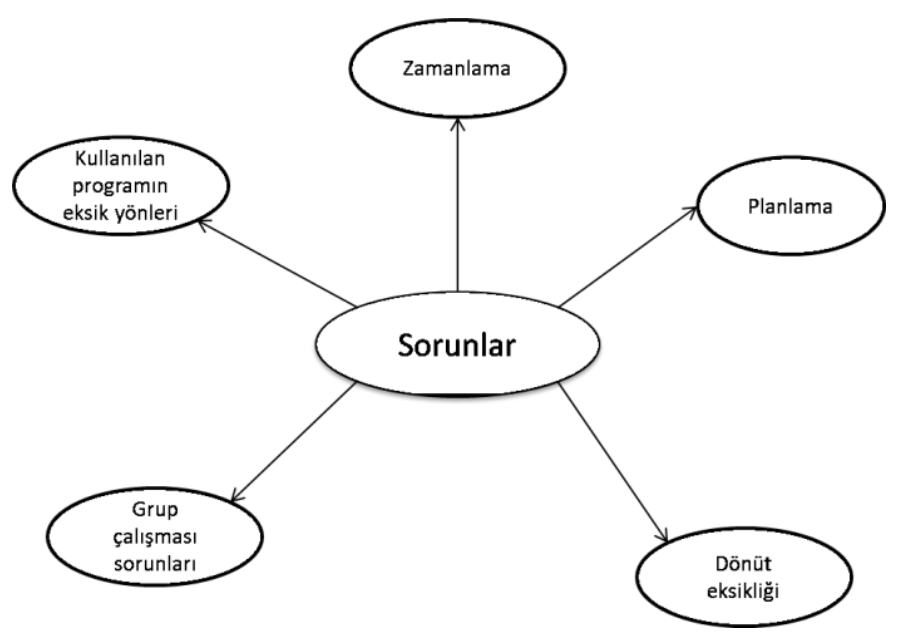

Şekil 9. Öğretmenlerin yaşamış oldukları sorunlar

Öğretmenler genel olarak proje süresinin kısa olmasından ve teorik derslerin de yer almasından memnun kalmadıklarını belirtmişlerdir. Bununla birlikte öğretmenlerin öykü yazımında zamanı etkili kullanamamalarından dolayı etkinliklerin yetiştirilmesinde bir takım sorunlar yaşanmış ve öykü değerlendirmeleri kısa tutulmak zorunda kalınmıştır. Ancak öğretmenler dönüt eksikliğinden rahatsız olmuşlardır. Öğretmenlerin görüşme sorusuna verdikleri cevaplardan örnekler aşağıda verilmiştir.

"...hikâyelere bir dönüt olumlu-olumsuz eleştiri değgerlendirme yapılmadı." (Ö11)

"...Kalabalık grupla çalışmak zaman açısından görüş birliği açısından bazı sıkıntılar oluşturdu." (Ö21)

Öğretmen adaylarının proje sürecinde yaşadıkları sorunlara ilişkin oluşan temalar Şekil 10'da gösterilmiştir.

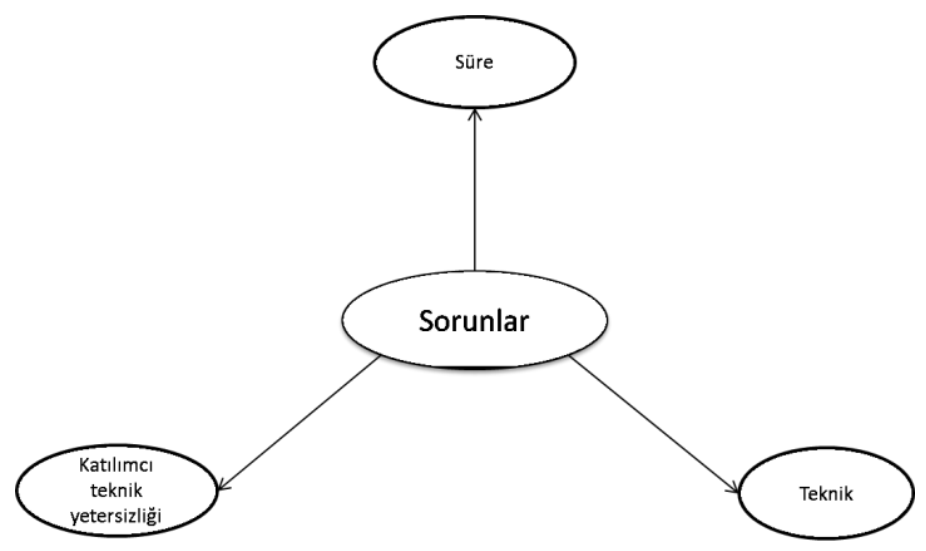

Şekil 10. Öğretmen adaylarının yaşamış oldukları sorunlar

Öğretmen adayları da öğretmenler gibi bazı etkinlikleri yetiştirme konusunda sorun yaşamışlardır. Özellikle dijital öykü programlarını daha önce kullanmamalarından dolayı uygulama aşamasında endişe duymuşlardır. Öğretmen adaylarının görüşme sorusuna verdikleri cevaplardan örnekler aşağıda verilmiştir.

"Bilgisayar ve yabancı dil konusunda eksik olduğumu fark ettim..." (ÖA5) 
"Zaman sorunumuz vardı. Bazı etkinlikleri yetiştirmekte sıkıntı yaşadık. Bunlar hem bizim detaycı oluşumuzdan hem de teknik açıdan var olan sorunlardı" (ÖA7)

Öğretmenlerin proje sürecinde yaşadıkları sorunlara ilişkin getirmiş oldukları çözüm önerilerine yönelik oluşan temalar Şekil 11'de gösterilmiştir.

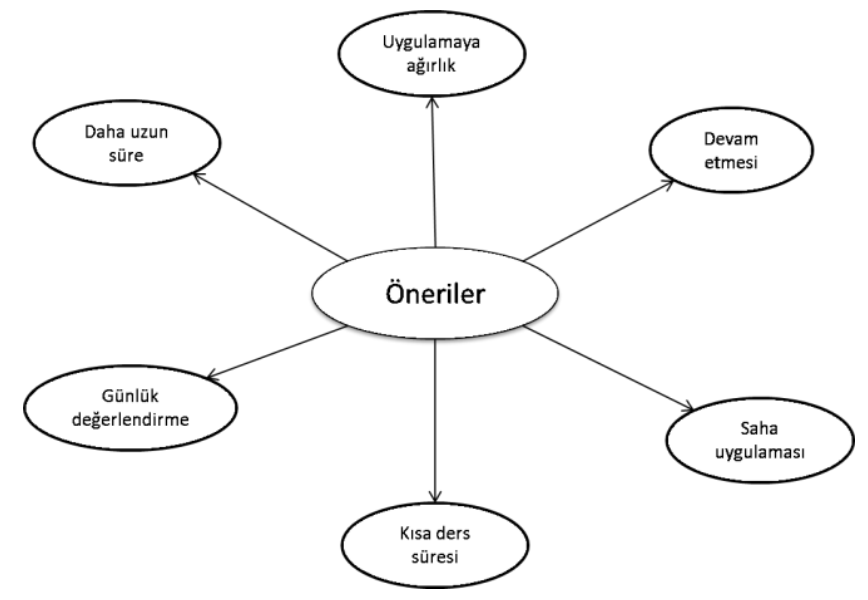

Şekil 11. Öğretmenlerin getirmiş oldukları öneriler

Öğretmenler bu uygulamalar esnasında karşılaştıkları sorunları da düşünerek ileride yapılacak olan çalışmalar için yapıcı öneriler geliştirmişlerdir. Öğretmenlerin görüşme sorusuna verdikleri cevaplardan örnekler aşağıda verilmiştir.

“...Bu tarz projelerde süre biraz daha uzun olabilir. Ya da katılımcilarn saha uygulamalarn yapmalarn şartıyla projenin devamı getirilebilir." (Ö15)

"Zaman kısaydı. Mutlaka uzatılmalı. Hikâye değerlendirme ile ilgili bir etkinlik mutlaka konulmalı." (Ö20)

Öğretmen adaylarının proje sürecinde yaşadıkları sorunlara ilişkin getirmiş oldukları çözüm önerilerine yönelik oluşan temalar Şekil 12' de gösterilmiştir.

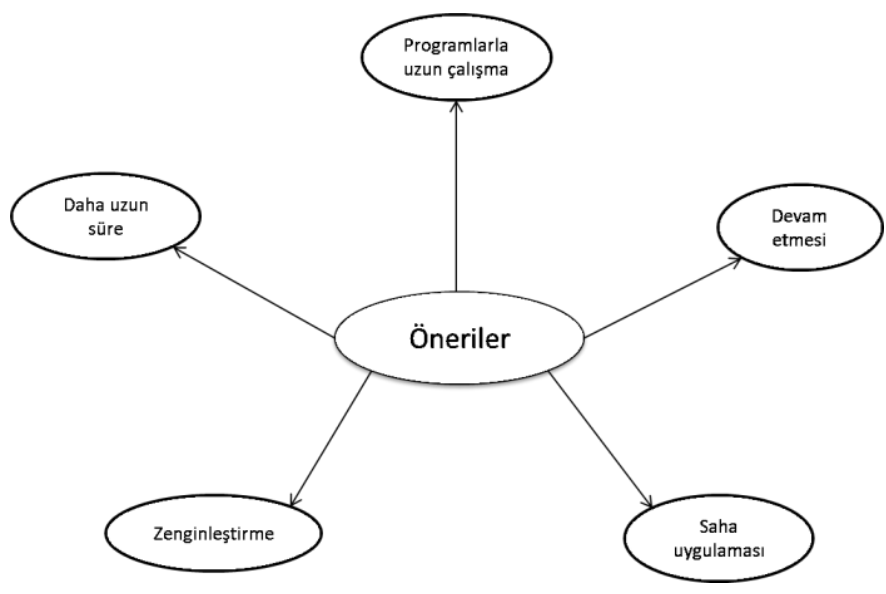

Şekil 12. Öğretmen adaylarının getirmiş oldukları öneriler verilmiştir.

Öğretmenlerin görüşme sorusuna verdikleri cevaplardan örnekler aşağıda

"Daha fazla zamanda daha kaliteli çalışmalar yapabilirdik" (ÖA2) 
“...programlarda daha uzun çalışma şansı bulabilirsek daha iyi olur." (ÖA9)

\section{Tartışma, Sonuç ve Öneriler}

Araştırmanın amacı doğrultusunda proje kapsamında gerçekleştirilen dijital öykü atölyesi etkinliklerinin katılımcların bilgisayar destekli eğitim yapmaya ilişkin tutumları üzerindeki etkisi incelenmiştir. Elde edilen bulgulara göre sınıf öğretmeni ve sınıf öğretmeni adaylarının bilgisayar destekli eğitim yapmaya ilişkin tutum puanlarının uygulamalar öncesi ve sonrasında anlamlı bir biçimde farklılık göstermediği belirlenmiştir. Ancak uygulamalar sonrasında katılımcıların puanlarında artış olduğu tespit edilmiştir. Bu sonuca göre dijital öykü atölyesi uygulamalarının sınıf öğretmeni ve sınıf öğretmeni adaylarının bilgisayar destekli eğitim yapmaya ilişkin tutumları üzerinde olumlu etki yaptığı söylenebilir. Uygulama süresinin kısa olmasından dolayı istatistiksel olarak anlamlı bir farklılık oluşmadığı düşünülmektedir. Tatlı ve Aksoy (2017) tarafından yapılan çalışmada dijital öykü sürecinin bilgisayar kullanım becerilerine ve tutuma olumlu yönde katk1 sağladığına değinilmektedir. Butler (2007) tarafından yapılan doktora tez çalışmasında dijital öyküleme uygulamalarının öğretmenlerin bilgisayarlara karşı tutumlarını olumlu yönde etkilediği belirtilmiştir.

Elde edilen bulgulara göre bir katılımcı dışında diğer katılımcıların dijital öyküleme yöntemini uygulanabilir buldukları belirlenmiştir. $\mathrm{Bu}$ durum proje etkinlikleri sonucunda sınıf öğretmeni ve sınıf öğretmeni adaylarının öğretmeöğrenme süreçlerinde dijital öyküleme yöntemini uygulama yeterliklerini kazandıklarını göstermektedir. Bununla birlikte bu sonuca göre katılımcıların dijital öyküyü kullanma konusunda istekli oldukları düşünülebilir. Yapılan araştırmalarda katılımcıların dijital öyküleri sınıf içinde kullanma konusunda istekli oldukları belirtilmektedir (Doering, Beach ve O'Brien, 2007; Sadik, 2008).

Elde dilen bulgulara göre sınıf öğretmeni ve sınıf öğretmeni adaylarının dijital öyküleme sürecinin birçok katkısına değindikleri belirlenmiştir. Öğretmenler dijital öyküleme sürecinin en çok hikâyeleri planlama konusunda yarar sağladığını belirtirken, öğretmen adayları en çok imaj-resim oluşturma ile hikâye ile ilgili materyalleri bütünleştirme konusunda yarar sağladığını belirtmişlerdir. Katılımcılar aynı zamanda dijital öyküleme sürecinin derse dikkat çekmede, kazanımların amacına somut ulaşmasında, teknoloji ile ürün ortaya koymada, metnin ana fikrini belirlemede, eleştirel düşünmede ve yaratıcı fikir bulmada katkı sağladığını belirtmişlerdir. Kotluk ve Kocakaya (2015), tarafından yapılan çalışmada öğrencilerin dijital öykülemenin planlama konusunda faydasına dikkat çektiklerinden bahsetmişlerdir. Bununla birlikte yapılan çalışmalarda dijital öykülemenin yaratıclık, eleştirel düşünme ve teknoloji kullanımı üzerinde olumlu etkileri olduğu belirtilmektedir (Duveskog, Tedre ve Sedano ve Sutinen, 2012; Michalski, Hodges ve Banister, 2005; Yoon, 2013).

Nitel verilerin analizinden elde edilen bulgulara göre sınıf öğretmenleri ve sınıf öğretmeni adaylarının uygulamalara, proje ekibine ve katılımcılara yönelik olumlu düşüncelere sahip oldukları belirlemiştir. Katılımcılar genel olarak uygulamaların mesleki anlamda kendilerine katkı sağlayacağını düşündüklerini belirtmişlerdir. Daniels (2013), araştırmasında dijital öykülerin öğretmen adaylarının alan deneyimlerinde pedagojik açıdan değişim yaşayarak öğretmen niteliklerinin artırılabileceğini belirtmektedir. Bu araştırmada da öğretmen ve öğretmen adaylarına 
etkinlikler aracılığıyla bu imkân sağlanmış ve onların olumlu duygu ve düşüncelere sahip oldukları belirlenmiştir. Aynı zamanda katılımcıların proje ekibi ve diğer katılımcılarla etkileşimli bir süreç yaşamaları sağlanmış ve bu durum onların düşüncelerine olumlu bir biçimde yansımıştır.

Katılımcıların bu süreç içerisinde yaşamış oldukları sorunlar incelendiğinde genel olarak sürenin kısa olmasından kaynaklı problemler yaşandığ Bazı katılımcıların çalışmalarını yetiştirme konusunda problem yaşaması onların motivasyonlarını olumsuz yönde etkilemiştir. Bu doğrultuda katılımcılar genel olarak bu çalışmanın daha fazla zamana yayılarak yapılmasını önermişlerdir. Dijital öyküleme ile ilgili yapılana araştırmalarda genel olarak zaman problemi yaşandığ1 belirtilmektedir (Gömleksiz ve Pullu, 2017; Karakoyun, 2014). Bu durumun katılımcıların teknoloji kullanım becerilerinin düşük olması ya da dijital öyküleme konusundaki deneyim eksikliklerinden kaynaklandığı düşünülmektedir.

Genel olarak bakıldığında TÜBITAK projesi kapsamında gerçekleştirilen dijital öykü atölyesi etkinliklerinin öğretmen ve öğretmen adaylarına birçok yönden katkı sağladığı söylenebilir. Katılımcılar bu tarz etkinliklerin kendilerine katkı sağladığını ve daha fazla yapılması gerektiğini düşünmektedirler. Günümüz öğrencilerinin dijital dünyaya olan ilgilerini göz önüne alarak öğretme-öğrenme sürecinde bu dünyaya uygun yöntem, teknik ve stratejilerin geliştirilmesi ve eğitimcilere bu uygulamaların tanıtılması önerilmektedir. Dijital öyküleme yöntemi gibi öğretmen ve öğretmen adaylarının teknopedagojik alan bilgilerini geliştirmeye yönelik uygulamalar içeren farklı çalışmalar gerçekleştirilebilir. Türkiye'nin farklı bölgelerinde görev yapan eğitimcilere verilecek eğitimler ile bu uygulamaların yaygınlaştırılması sağlanabilir. Bununla birlikte moderatör öğretmen eğitimleri düzenlenerek öğretmenlerin kendi bölgelerindeki öğretmenlere katıldıkları bu uygulamaları tanıtmaları sağlanabilir. Yapılacak olan farklı çalışmalarda öğrenciler de sürece dâhil edilebilir. Öğretmen ve öğretmen adaylarına verilen eğitimler öğrenciler ile uygulamalı olarak değerlendirilebilir.

\section{Kaynakça}

Arslan, A. (2006). Bilgisayar destekli eğitim yapmaya ilişkin tutum ölçeği. Yüzüncü Yıl Üniversitesi Ĕ̆itim Fakültesi Dergisi, 3(2), 24-33.

http:/ / toad.edam.com.tr/sites/default/files/pdf/bilgisayar-destekli-egitimyapmaya-iliskin-tutum-olcegi-toad.pdf adresinden alınmıştır.

Balaman, F. (2016). Dijital öykülemenin üniversite öğrencilerinin demokratik değer yargilarına etkisi: Mustafa Kemal Üniversitesi örneği. Current Research in Education, 2(1), 42-52. http://dergipark.gov.tr/crd/issue/24869/262803 adresinden alınmıştır.

Butler, J. W. (2007). Teachers' attitudes toward computers after receiving training in lowthreshold digital storytelling applications (Yayımlanmamış doktora tezi). Houston Üniversitesi.

Büyüköztürk, Ş. (2012). Sosyal bilimler için veri analizi el kitabı. (17. Basım). Pegem Akademi Yayınları, Ankara.

Chung, S. K. (2007). Art education technology: digital storytelling. Art Education, 60(2),16-22. https:/ / doi.org/10.1080/00043125.2007.11651632

Creswell, J. W. and Plano Clark, V. L. (2015). Karma yöntem araştırmaları tasarımı ve yürütülmesi. (Ed. Y. Dede ve S. B. Demir), Ankara: Anı Yayıncılık. 
Creswell, J. W. (2012). Qualitative inquiry and research design: Choosing among five approaches. California: Sage Publications.

Daniels K. (2013). Exploring the impact of critical reflection through the use of service learning and digital storytelling. I-manager's Journal On School Educational Technology, 9(1),1-9. https:// doi.org/10.26634/jsch.9.1.2396

Doering, A.,Beach, R.and O'Brien, D. (2007).Infusing multi modal tools and digital literacies into an English education program. English Education, 40(1), 41-60. https:/ / www.jstor.org/stable/40173267?seq=1\#page_scan_tab_contents adresinden alınmıştır.

Duveskog, M.,Tedre, M., Sedano, C. I., and Sutinen, E. (2012). Life planning by digital story telling in a primary school in Rural Tanzania. Educational Technology $\mathcal{E}$ Society, 15(4), 225-237. https://www.j-ets.net/ETS/journals/15_4/20.pdf adresinden alınmiştır.

Educational Uses of Digital Storytelling, (2017). Educational Uses of Digital Storytelling web sitesi.

http:/ / digitalstorytelling.coe.uh.edu/page.cfm?id=27\&cid=27\&sublinkid=31 adresinden alınmıştır.

Foley, L.M. (2013). Digital storytelling in primary-grade classrooms. Unpublished Doctoral Dissertation, University of Arizona State: USA.

Gömleksiz, M. N., ve Pullu, E. K. (2017). Toondoo ile dijital hikâyeler oluşturmanın öğrenci başarısına ve tutumlarına etkisi. Electronic Turkish Studies, 12(32), 95110. https:/ / doi.org/10.7827/TurkishStudies.12717

İnceelli, A. (2005). Dijital hikaye anlatımının bileşenleri. The Turkish Online Journal of Educational Technology, 4(3), 132-142.

http:/ / www.tojet.net/articles/v4i3/4318.pdf adresinden alınmıştır.

Karakoyun, F. (2014). Çevrimiçi ortamda oluşturulan dijital öyküleme etkinliklerine ilişkin ögretmen adaylarn ve ilköğretim öğrencilerinin görüşlerinin incelenmesi

(Yayımlanmamış Doktora Tezi). Anadolu Üniversitesi, Eğitim Bilimleri Enstitüsü, Eskişehir.

Koehler, M. J. and Mishra, P. (2008). Introducing technological pedagogical knowledge. In AACTE (Ed.), The handbook of technological pedagogical content knowledge for educators, (3-30), New York and London: Routledge.

Kotluk, N., ve Kocakaya, S. (2015). 21. yüzyıl becerilerinin gelişiminde dijital öykülemeler: Ortaöğretim öğrencilerinin görüşlerinin incelenmesi. Eğitim ve Öğretim Araştırmaları Dergisi, 4(2), 354-363. 01 Ağustos 2018 tarihinde http:/ / www.jret.org/FileUpload/ks281142/File/36.nihat_kotluk..pdf adresinden alınmıştır.

Mello, R. (2001). The power of storytelling: How oral narrative influences children's relationships in classrooms. International Journal of Education and the Arts, 2(1), 1-14. http:/ / www.ijea.org/v2n1/ adresinden alınmıştır.

Michalski, P., Hodges, D., and Banister, S. (2005). Digital storytelling in the middle childhood special education classroom: A teacher's story of adaptations. Teaching Exceptional Children Plus, 1(4), 1-13.

http:/ / escholarship.bc.edu/education/tecplus/vol1/iss4/3 adresinden alınmıştır.

Ohler, J. (2008). Digital storytelling in the classroom. Corwin Press, Thousand Oaks, CA. 
Pamuk, S., Ülken, A., ve Dilek, N. Ş. (2012). Öğretmen adaylarının öğretimde teknoloji kullanım yeterliliklerinin teknolojik pedagojik içerik bilgisi kuramsal perspektifinden incelenmesi. Mustafa Kemal Üniversitesi Sosyal Bilimler Enstitüsü Dergisi, 9(17), 415-438.

http:/ / sbed.mku.edu.tr/article/view/1038000251/1038000102 adresinden alınmıştır.

Robin, B. (2006). The educational uses of digital storytelling. In C. Crawford et al. (Eds.), Proceedings of Society for Information Technology and Teacher Education International Conference 2006 (pp. 709-716). Chesapeake, VA: AACE.

Robin, B. R., and McNeil, S. G. (2012). What educators should know about teaching digital storytelling. Digital Education Review, 22, 37-51. 06 Haziran 2018 tarihinde http:/ / revistes.ub.edu/index.php/der/article/view/11294 adresinden alınmıştır.

Sadik, A. (2008). Digital storytelling: A meaningful technology-integrated approach for engaged student learning. Educational Technology Research and Development, 56(4), 487-506. https:/ / doi.org/10.1007/s11423-008-9091-8

Tatl1, Z., ve Aksoy, D. A. (2017). Yabancı dil konuşma eğitiminde dijital öykü kullanımı. Marmara Üniversitesi Atatürk Ĕ̆itim Fakültesi Ĕ̆itim Bilimleri Dergisi, 45, 137-152. https:// doi.org/10.15285/maruaebd.271060

Yang, Y.-T. C. and Wu, W.-C. I. (2012). Digital storytelling for enhancing student academic achievement, critical thinking, and learning motivation. A year-long experimental study. Computers $\mathcal{E}$ Education, 59(2), 339-352. https:// doi.org/10.1016/j.compedu.2011.12.012

Yıldırım, A. ve Şimşek, H. (2016). Sosyal bilimlerde nitel araştırma yöntemleri. Ankara: Seçkin Yayıncılık.

Yılmaz, Y., Üstündağ, M. T., Güneş, E. (2017). Öğretim materyali olarak dijital hikâye geliştirme aşamalarının ve araçlarının incelenmesi. Abant Izzet Baysal Üniversitesi Eğitim Fakültesi Dergisi, 17(3), 1621-1640. https:// doi.org/10.17240/aibuefd.2017.17.31178-338851

Yoon, T. (2013). Are you digitized? Ways to provide motivation for ells using digital storytelling. International Journal of Research Studies in Educational Technology, 2(1), 25-34. https:// doi.org/10.5861/ijrset.2012.204

\section{Summary}

\section{Introduction}

The root of digital storytelling is coming from the storytelling that has been used as an educational tool from past to present. As it is stated by Mello (2001), storytelling is one of the oldest methods that is used to explain ideas and images. Digital storytelling, also, is defined as a creative process in which individual digital technologies such as computer, video camera and audio recorder are combined with traditional stories (Ohler, 2008). In this sense, it can be said that digital storytelling is a digital form of traditional storytelling method. The studies on digital storytelling were initiated in "Digital Media Center" founded in San Francisco in 1994. Nowadays, it has been commonly used from preschool to adult education abroad. 
The studies in this field reveal the positive effects of digital storytelling method on students. Digital storytelling method can increase the academic success of students; it can also contribute to the development of positive attitudes to courses; it improves writing skills, critical thinking and problem solving abilities; it increases democratic values; it helps to the permanence of courses, and finally it positively contributes to students' self-expression (Balaman, 2016; Foley, 2013; Robin, 2006; Tatl1 \& Aksoy, 2017; Yang \& Wu, 2012; Yoon, 2013). Taking these contributions to students into account, it is thought that the use of digital storytelling method by teachers can positively affect teaching process. Accordingly, in this study, a project study is conducted in which theoretical and practical dimensions of this method are presented in an integrative way for both in-service and pre-service teachers.

The aim of this study is to determine the effect of digital storytelling workshops designed for the project on the attitudes of participants for the use of computer-assisted learning and to examine the experiences of participants during the project.

\section{Method}

In this study, mixed method research has been used. Since the aim of this study was to determine the effect of digital storytelling workshops designed for the project on the attitudes of participants towards the use of computer-assisted learning and to examine the experiences of participants during the project, this research method was preferred for the study.

As for the sampling of the study, criterion sampling method which is a type of purposive sampling methods was used. Because the activities of the project were designed specifically for pre-service and in-service primary school teachers, purposive sampling method was preferred for the study. At the same time, in order to supply a common effect for the project, four in-service primary school teachers - 2 males and 2 females- and four pre-service primary school teachers -2 males and 2 females- in each region have been determined as the criteria by the project team. As for the first step of the project, 28 in-service primary school teachers have been determined as the participants; as for the second step of the project, 28 pre-service primary school teachers have been determined as the participants of this project.

As for the data collection instrument, "The Attitude Scale Toward Making Computer Supported Education" designed by Arslan (2006) and an interview form designed by the researchers were used to collect data.

The practices of the project were conducted in two steps. In the first step named as "In-service Teachers are in the Digital Storytelling Workshop" was realized with 28 in-service primary school teachers who came from seven different regions in Turkey. In the second step named as "Pre-service Teachers are in the Digital Storytelling Workshop" was realized with 28 pre-service primary school teachers. The participants attended the activities as accommodated. The activities designed for both pre-service and in-service teachers were applied for four days. The activities were realized as group work activities with the participants. In each step, seven groups consisting of four participants were designed. Thanks to this way, the use of brainstorming for completing activities was enabled for the participants. At the end of the project, both pre-service and in-service teachers could design their own digital stories as a group. 
In the data analysis process, Shapiro-Wilks Levene's Variance Homogeneity Test, skewness and kurtosis values and Wilcoxon Signed Rank Test were used in the project. As for the qualitative data analysis, content analysis was used.

\section{Results}

According to the findings of the data analysis, it was determined that the attitude scores of both pre-service and in-service teachers on the use of computer-assisted teaching increased; however, it was seen that the increase was not statistically meaningful.

It was found that apart from one participant, all of the teachers thought that digital storytelling method could be applied. According to the findings, it was determined that in-service teachers thought the use of digital storytelling could mostly contribute to planning a story; pre-service teachers thought that this method could be mostly useful for creating image-picture and combining stories and materials. However, it was also revealed that in-service and pre-service teachers thought digital storytelling process could be helpful for getting attention, gaining learning outcomes concretely, producing products via technology, understanding the main idea of a story, improving critical thinking and finding creative ideas. Accordingly, it was concluded that the participants had positive attitudes toward the activities, project team and the other participants. Additionally, the participants stated that they had some problems due to the lack of time and they also stated that those kinds of projects should go on. In general, it was determined that the project experiences of the participants were positive.

\section{Discussion}

It can be said that digital storytelling workshops positively affected pre-service and in-service teachers' attitudes on the use of computer-assisted teaching process. In a study conducted by Tatlı and Aksoy (2017), it was pointed out that digital storytelling process could positively affect the skills on the use of computer and attitudes to this context. As a result of project activities, it was determined that preservice and in-service teachers could gain proficiency on the use of digital storytelling in their teaching-learning process. Additionally, according to this finding, it can be thought that the participants were eager to use digital storytelling. In the studies, it was determined that participants were eager to use digital storytelling in their classrooms (Doering, Beach \& O'Brien, 2007; Sadik, 2008).

According to the findings of this project, it was seen that pre-service and inservice teachers stated many contributions to digital storytelling process. In their study, Kotluk and Kocakaya (2015) mentioned that learners pointed out the benefits of digital storytelling to making plan. Additionally, in the studies related with this issue, it was stated that digital storytelling had a positive effect on creativity, critical thinking and the use of technology (Duveskog, Tedre, Sedano \& Sutinen, 2012; Michalski, Hodges \& Banister, 2005; Yoon, 2013).

The participants stated that this project would contribute to their professional life. Daniels (2013), in a study, revealed that digital stories could develop teacher qualities such as getting a transformation in terms of pedagogical content knowledge in the experiences of pre-service teachers. In this study, also, preservice and in-service teachers were enabled to develop themselves via activities 
designed in the project and it was determined that the participants had positive attitudes and ideas on the project. Additionally, an interactive process with the project team and the participants was organized and this was reflected in their thoughts positively.

When the participants' problems in the process were examined; in general, it was seen that the reason of those problems were based on lack of the duration. In general, in the studies about digital storytelling, it has been stated that there can be problems because of limited time (Gömleksiz \& Pullu, 2017; Karakoyun, 2014). It is thought that the reason of these problems can arise from having limited skills on the use of technology and lack of experience on digital storytelling.

\section{Ek 1}

\section{Proje Etkinlik Bilgileri}

\begin{tabular}{|c|c|c|}
\hline Etkinlik İsmi & Etkinlik Amacı & Etkinlik İçeriği \\
\hline $\begin{array}{l}\text { Tanitım } \\
\text { Toplantısı }\end{array}$ & $\begin{array}{l}\text { Katılımcilara proje } \\
\text { hakkında bilgi vermek } \\
\text { ve projeyi tanıtmak }\end{array}$ & $\begin{array}{l}\text { Katılımcılara ve toplantıya katılan izleyicilere proje } \\
\text { süreci hakkında bilgi verilmiştir. Daha sonra proje ekibi } \\
\text { tarafından katılımcılara proje kiti ve yaka kartları } \\
\text { dağıtılmıştır. }\end{array}$ \\
\hline Çak Bir Beşlik & $\begin{array}{l}\text { Proje katılımcılarının } \\
\text { birbirlerini ve projede } \\
\text { görevli personeli } \\
\text { tanımalarını ve } \\
\text { etkileşim kurmalarını } \\
\text { sağlayarak güvenli ve } \\
\text { pozitif bir sınıf ortamı } \\
\text { oluşturmak }\end{array}$ & $\begin{array}{l}\text { Katılımcılarla drama etkinlikleri gerçekleştirilmiştir. } \\
\text { Daha sonra proje ön test uygulamaları } \\
\text { gerçekleştirilmiştir. }\end{array}$ \\
\hline $\begin{array}{l}\text { Farkında } \\
\text { Misınız? }\end{array}$ & $\begin{array}{l}\text { Katılımcıların öğretim } \\
\text { yöntem ve tekniklerine } \\
\text { ilişkin bilgilerini } \\
\text { hatırlatmak, ortaya } \\
\text { çıkartmak ve kullanım } \\
\text { yerlerini tartışmak }\end{array}$ & $\begin{array}{l}\text { Katılımcılara sınıf içerisinde uygulanan etkili yöntem, } \\
\text { teknik ve stratejiler hakkında bilgi verilmiştir. Etkinlik } \\
\text { içeriği "polleverywhere" ile bütünleştirilmiş ve } \\
\text { katılımcıların farklı bir öğretim teknolojisini tanımaları } \\
\text { sağlanmıştır. }\end{array}$ \\
\hline $\begin{array}{l}\text { Öykülemeye } \\
\text { Giden Yol }\end{array}$ & $\begin{array}{l}\text { Katılımcılara } \\
\text { öyküleme yöntemi } \\
\text { hakkında bilgi vermek }\end{array}$ & $\begin{array}{l}\text { Katılımcılara öyküleme yöntemi hakkında bilgi } \\
\text { verilmiştir. Öyküleme yönteminde kullanılan } \\
\text { stratejilerden hikaye robotu, hikaye yüzü, hikaye } \\
\text { piramidi ve hikaye haritasının nasıl kullanılacağı } \\
\text { örnekler ile anlatılmıştır. Daha sonra grup çalışması } \\
\text { olarak katılımcılara öyküleme çalışmaları } \\
\text { yaptırılmıştır. }\end{array}$ \\
\hline $\begin{array}{l}\text { Derslerin } \\
\text { Öyküsü }\end{array}$ & $\begin{array}{l}\text { Katılımcılarla örnek } \\
\text { öyküleme çalışması } \\
\text { yapmak }\end{array}$ & $\begin{array}{l}\text { Katılımcılar bu etkinlikte bir önceki etkinlikte görülen } \\
\text { öyküleme yöntemine göre ders içerikli öyküler } \\
\text { hazırlamışlardır. Katılımcılara daha sonra bu öykü } \\
\text { metinlerini dijital forma dönüştürecekleri söylenmiş ve } \\
\text { proje ekibi tarafından öykü çalışmalarına rehberlik } \\
\text { yapılmıştır. }\end{array}$ \\
\hline $\begin{array}{l}\text { Öykülemede } \\
\text { Yeni Bir } \\
\text { Sekme }\end{array}$ & $\begin{array}{l}\text { Katılımcılara dijital } \\
\text { öyküleme hakkında } \\
\text { bilgi vermek }\end{array}$ & $\begin{array}{l}\text { Katılımcılara dijital öyküleme yönteminin kuramsal } \\
\text { temelleri, tarihsel süreci, dijital öyküleme türleri, dijital } \\
\text { öykülemenin öğeleri, dijital öyküleme süreci, eğitimde } \\
\text { dijital öyküleme yönteminin önemi ile ilgili sunum } \\
\text { yapılmıştır. Sonra proje yürütücüsü tarafından } \\
\text { "Tikırdatanlar ve Dinleyenler" } \\
\text { gerçekleştirilmiştir. }\end{array}$ \\
\hline
\end{tabular}




\begin{tabular}{|c|c|c|}
\hline $\begin{array}{l}\text { Dijital Öykü } \\
\text { Sinıf1 }\end{array}$ & $\begin{array}{l}\text { Dijital öyküleme } \\
\text { yönteminin sınıf içi } \\
\text { uygulamalarını } \\
\text { göstermek }\end{array}$ & $\begin{array}{l}\text { Proje yürütücüsü, uzmanlar ve eğitmenler tarafından } \\
\text { hazırlanan ders içerikli dijital öyküler katılımcılara } \\
\text { izletilmiş ve sinıf içi uygulamaları katılımcılar ile } \\
\text { gerçekleştirilmiştir. Bu etkinlikte dijital öyküler } \\
\text { canlandırma, sokratik sorgulama, istasyon yöntemi ve } \\
\text { kart eşleştirme teknikleri ile birlikte kullanılmıştır. }\end{array}$ \\
\hline Tekno Boyut & $\begin{array}{l}\text { Katılımcılara dijital } \\
\text { öykülemede } \\
\text { kullanılacak } \\
\text { programların } \\
\text { tanıtılması }\end{array}$ & $\begin{array}{l}\text { Proje kapsamında kullanılacak olan "Tondoo" ve } \\
\text { "Microsoft Photostory 3" programları tanıtılmış ve } \\
\text { katılımcılarla örnek uygulamalar gerçekleştirilmiştir. }\end{array}$ \\
\hline $\begin{array}{l}\text { Doğada Öykü } \\
\text { Temaları }\end{array}$ & $\begin{array}{l}\text { Doğa gezisi ile } \\
\text { katılımcıların } \\
\text { oluşturacakları kendi } \\
\text { dijital öykülerinde } \\
\text { kullanabilecekleri } \\
\text { fotoğraflar çekebilmek }\end{array}$ & $\begin{array}{l}\text { Katılımcılar doğal güzellikleri olan bir gezide kendi } \\
\text { kişisel dijital öyküleri için fotoğraflar çekmişlerdir. }\end{array}$ \\
\hline $\begin{array}{l}\text { Öyküler } \\
\text { "Biz"de } \\
\text { Canlanıyor }\end{array}$ & $\begin{array}{l}\text { Katılımcıların doğa } \\
\text { gezisinde elde ettikleri } \\
\text { fotoğrafları kullanarak } \\
\text { yazdıkları öyküleri } \\
\text { dijital öykülere } \\
\text { çevirmelerini } \\
\text { sağlamak }\end{array}$ & $\begin{array}{l}\text { Katılımcılar doğa gezisinde çekmiş oldukları } \\
\text { fotoğraflar ile "Microsoft Photostory } 3 \text { " programında } \\
\text { kişisel dijital öyküler hazırlamışlardır. Daha sonra bu } \\
\text { dijital öyküler sınıf içerisinde izlenerek katılımcılara } \\
\text { dönütler verilmiştir. }\end{array}$ \\
\hline $\begin{array}{l}\text { Öyküler } \\
\text { "Sinıf"ta } \\
\text { Canlanıyor }\end{array}$ & $\begin{array}{lr}\text { Katılımcıların } & \text { sınıf içi } \\
\text { etkinliklere } & \text { yönelik } \\
\text { yazdıkları } & \text { öyküleri } \\
\text { dijital } & \text { öykülere } \\
\text { çevirmelerini } & \\
\text { sağlamak } & \end{array}$ & $\begin{array}{l}\text { Katılımcılar daha önceki etkinliklerde yazmış } \\
\text { oldukları ders içerikli öyküleri "Tondoo" ve } \\
\text { "Microsoft Photostory } 3 \text { programlarını kullanarak } \\
\text { dijital öykülerini hazırlamışlardır. Süreç içerisinde } \\
\text { proje ekibi katılımcılara rehberlik yapmış ve dijital } \\
\text { öyküler hazırlanırken yaşanan sorunlar çözülmüştür. }\end{array}$ \\
\hline Kaydet, paylaş & $\begin{array}{lr}\text { Katılımcılar tarafından } \\
\text { hazırlanan } & \text { dijital } \\
\text { öykülerin } & \\
\text { katılımcılarla } & \text { birlikte } \\
\text { izlenmesi } & \text { ve } \\
\text { hazırlanan } & \text { öyküler } \\
\text { üzerinden } & \\
\text { katılımcılara } & \text { dönüt } \\
\text { verilmesi } & \end{array}$ & $\begin{array}{l}\text { Katılımcılar tarafından hazırlanan dijital öyküler proje } \\
\text { ekibi ve tüm katılımcılar ile birlikte izlenmiş ve } \\
\text { değerlendirilmiştir. }\end{array}$ \\
\hline $\begin{array}{l}\text { Değerlendirme } \\
\text { ve Kapanış }\end{array}$ & $\begin{array}{l}\text { Proje çalışmasının } \\
\text { değerlendirmesini } \\
\text { yapmak }\end{array}$ & $\begin{array}{l}\text { Katılımcılar ve tüm proje ekibi ile birlikte proje } \\
\text { çalışması değerlendirilmiştir. Proje son test } \\
\text { uygulamaları gerçekleştirilmiştir. }\end{array}$ \\
\hline
\end{tabular}

\section{Authors' Biodata/ Yazar Bilgileri}

Güler GÖÇEN KABARAN Muğla Sıtkı Koçman Üniversitesi, Eğitim Fakültesi, Eğitim Programları ve Öğretim Bölümü'nde araştırma görevlisi olarak çalı̧̧maktadır. Araştırma alanları, program geliştirme ve değerlendirme, öğretmen eğitimi, öğrenme ve öğretme becerileri, eğitim teknolojisi, dijital materyal tasarımıdır.

Güler GÖÇEN KABARAN She has been working as a research assistant at Muğla Sitkı Koçman University, Faculty of Education, Department of Curriculum and Instruction. Her research interests are curriculum development and assessment, 
teacher training, learning and teaching skills, educational technology, digital material design.

Halit KARALAR Muğla Sıtkı Koçman Üniversitesi, Bilgisayar ve Öğretim Teknolojileri Eğitimi Bölümü'nde Doktor Öğretim Üyesi olarak çalışmaktadır. Uzmanlık alanları Anlamsal Web Teknolojileri, e-Öğrenme, Öğretim Tasarımı Kuram ve Modelleri ve Öğretimsel Mesaj Tasarımıdır.

Halit Karalar is working as a faculty member in Computer Education and Instructional Technology Department at Muğla S1tk1 Koçman University. His areas of specialization are Semantic Web Technologies, e-Learning, Instructional Design Theories and Models, and Instructional Message Design.

Bilge ASLAN ALTAN Muğla Sıtkı Koçman Üniversitesi, Eğitim Fakültesi, Eğitim Programları ve Öğretim Bölümü'nde araştırma görevlisi olarak çalışmaktadır. Araştırma alanları, öğretmen eğitimi, eğitim teknolojisi, ekstra program ve program değerlendirmedir.

Bilge Aslan Altan has been working as a research assistant at Muğla Sitkı Koçman University, Faculty of Education, Department of Curriculum and Instruction. Her research interests include teacher education, educational technology, extra program and program evaluation.

Sedat ALTINTAŞ Muğla Sitkı Koçman Üniversitesi, Eğitim Fakültesi, Eğitim Programları ve Öğretim Bölümü'nde araştırma görevlisi olarak çalışmaktadır. Araştırma alanları, matematik eğitimi, program geliştirme ve değerlendirme, öğretmen yetiştirme, öğrenme ve öğretme becerileridir.

Sedat Altıntaş has been working as a research assistant at Muğla Sitkı Koçman University, Faculty of Education, Department of Curriculum and Instruction. His research interests are math education, curriculum development and assessment, teacher training, learning and teaching skills. 